\title{
Concrete Steps of Albania Towards the Approximation of National Legislation with the Acquis Communautaire: Is it Considered that the Copenhagen Criteria in this Sector is Fulfilled?

\author{
Gledina Mecka, PhD Candidate
}

National Bar Association, Albania; Email: jurist.gledina@gmail.com

MSc. Anton Bardhaj

National Bar Association, Albania; Email: bardhajanton@gmail.com

\author{
Doi:10.5901/ajis.2015.v4n3s1p293
}

\section{Abstract}

\begin{abstract}
Laws are the foundations of a democratic state and their implementation becomes easier to serve to citizens if the state (in our case Albania) achieves the necessary drafting standards. Countries with the EU integration perspective should guarantee the fulfillment of these standards. In 1993, the European Council determined in its conclusions the Copenhagen Criteria. One of them is compliance with the EU acquis. This is a non-negotiable condition for membership, which means that national legislation should be harmonized with the right of the EU as a whole, before Albania joins EU. Being aware of this fact, as well as obligations under the SAA to align EU acquis, the Albanian Government has prepared a National Plan for European Integration as a long-term plan extended for the period from 2014 to 2020. It is a dynamic document that will evolve with passing the stages of the integration process. This article treats the EU primary legislation, secondary legislation, the jurisprudence of the European Justice Court, etc., also principles and methods of approach. The main purpose of this paper is to present the steps taken by Albanian Government in the process of harmonization of domestic legislation with the acquis. It is focused on national strategies, actions, trainings and evaluations of EU bodies.
\end{abstract}

Keywords: acquis communautaire, domestic law, criteria, achievements, integration.

\section{Introduction}

In 1993, the European Council in its conclusions determined the Copenhagen Criteria. One of them is the compliance with the EU acquis. This is a non-negotiable condition for membership, which means that national legislation should be harmonized with the EU legislation, before Albania becomes a member state of the EU. In this paper, there are presented the harmonization notion and its necessity, the procedures required, the deadlines, principles, methods and the harmonization levels. Our country has been involved in this procedure since the signing of the SAA with the EU in 2006. One of the main duties in order to receive the candidate status and after that to become a member of EU is exactly the translation of the acquis, its transposition into the domestic law, law amendments and new law adoption.

\section{The Acquis Communautaire}

The definition of Acquis communautaire has been articulated for the first time in the opinion of the European Commission on 01.10.1969 on the request for accession submitted by the United Kingdom, Denmark, Ireland and Norway. While according to the most prominent Judge of the European Court of Justice, Pesccatore, "The Acquis which consists in the basic Articles 2 and 3 of the TEU is a superior acquis, which includes the essential elements, the conditions, which have to do with the very foundation of the Community, rules, which if violated would risk the unity, identity and the existence of European entrepreneurship."

The Treaty of Nice, which entered with force on 1 February 2003, brought a new element to the introduction of the term EU Acquis: With the Acquis Communautaire we must understand a set of rules, which constitute the core of the European building, without which its existence will be compromised. 


\section{Hierarchy of the Norms of the Acquis Communautaire}

The translation of the acquis for countries aspiring to join the EU must be made under this rule:

\subsection{Primary legislation}

It includes original treaties since the creation of the EC and later the EU and to the other Treaties of Amsterdam and Nice, as well as all the Treaties of Accession for member countries, the Constitutional Treaty and the Basic Charter of Human Rights. Signing the Treaty of Accession is accompanied by publication in the Official Bulletin of EU in the candidate country language.

\subsection{Secondary legislation}

Secondary legislation includes directives, regulations and decisions, which should be translated into candidate language and published in the Official Journal of the European Community at the time of accession.

Judicial decisions of the European Court of Justice as well as other sources should be translated into national languages.

\section{Key Principles of Community Legislation ${ }^{1}$}

The principle of direct effect and applicability, which enables the acquis to become part of the domestic law without the need of incorporating it through a local normative act. ${ }^{2}$

The principle of supremacy over domestic law, which means the transfer of rights and obligations of Member States, from the internal legal system to the Community legal system. This has the consequence of limitation the sovereign rights. So, a subsequent unilateral act, incompatible with the notion of community, cannot take precedence. Consequently, any normative act in domestic law cannot prevail over Community law and should be declared null and void. The same applies for the judiciary in interpreting the law. When there is a conflict between the EU law and the domestic law, Community law has always priority. ${ }^{3}$

The subsidiary and proportionality principles. The subsidiary principle means that the Community will not undertake or regulate in any way what is already adjusted in order to be effective at national or regional level. ${ }^{4}$ The principle of proportionality means that if for the achievement of a treaty objective it is necessary a particular action, the Community may not go beyond what is necessary to fulfill the objectives of this Treaty.

The principle of equality and protection from discrimination on the basis of citizenship, gender, etc.

With the above overview, was given the current notion of the Acquis Communautaire, the division of the acquis in primary and secondary sources as well as basic principles.

\section{Approximation of the Acquis as the Main Criteria of Copenhagen: National Plan for Approximation of the Legislation (NPAL).}

SAA contains only one article (Article 70/1 of the SAA with Albania) concerning the alignment, according to which Albania needs to ensure that current and existing laws will comply with the Acquis Coummunautaire gradually.

The SAA provides two categories of provisions concerning the approximation:

Horizontal provisions which are provided in Title VI "Alignment of legislation, enforcement and competition rules" and the relevant chapters, such as "General principles" which may be qualified as Lex generalis.

Vertical provisions which are contained in various articles of Title VIII, for example "Cooperation Policies" which are qualify as Lex Specialis.

SAA provided a timetable for the approximation of legislation. Article $70 / 2$ provides that this process will begin at

\footnotetext{
1 https://www.scribd.com/doc/33741493/Itap-materiali-Perafrimi-Legjislacionit-Me-Be\#scribd

2 Case of "Van Gend en Loos vs. Netherlands", ECJ 26/1963

${ }^{3}$ Article 5 of European Community Treaty

${ }^{4}$ Articles 12, 141, 251 of European Community Treaty
} 
the moment of signing and will be implemented in a transitional period of ten years. In the first five years would begin Frontline alignment in areas such as the single market, competition, intellectual property, public procurement, standards and financial services, etc. agreement.

Regarding the other sectors, the approximation obligation extends in a second phase of implementation of the

Being aware of the fact that the approximation of national legislation with the EU is the basic task for Albania according to the SAA as well as according to the Copenhagen Summit in 1993, the Albanian Government decided to prepare a National Plan for European Integration. The National Plan for European Integration is a long-term plan extending from 2014 to 2020. Approximation of legislation is an obligation which contributes to the future of the Albanian legal system to approach it with European standards. This is a process that extends to almost all areas of law, such as consumer protection, banking, insurance, criminal law, environmental law. Approximation covers EU acquis in its entirety. We are talking about hundreds of normative acts and the case law of the Court of Justice of the European Union. Activities are divided by chapters of the acquis with clear deadlines. For ease of reference, they are presented in tables showing the existing degree of compliance as well as priorities in the coming years, the timeline for their implementation as well as the division of responsibilities.

This part of the plan covers short and medium term measures (e.g. 2014-2016). This part of the plan will be updated annually to reflect the priorities for development in the process of European integration, as well as changes in the EU law itself. AP is a dynamic document that will evolve as we move on to other stages of the integration process.

The purpose of NPAL (National Plan for Approximation of the Legislation).

NPAL has meant to represent a comprehensive document in order to provide a single national framework for planning, setting priorities and monitoring the process of European integration in its different sectors. The plan aims to summarize all the necessary measures taken by Albania to approach the European Union within a sated timeframe. The plan seeks to address all issues arising from:

1. Thessaloniki Agenda, including political issues like the Common Foreign and Security Policy (which is also in Chapter 27 of the acquis) or other issues, which are not included or emphasized in particular in the European Partnership.

2. Recommendations of the CTF's reports and SAP.

3. The last European partnership, in terms of the improvements needed to provide more detailed information on the needs of staffing and training as well as on the cost of the measures planned.

4. Full implementation of the SAA/Interim as well as other agreements between Albania and EU.

5. In the NPAL, the objectives included are: The current situation (providing legal and institutional framework for measuring progress, short term priorities which included legislative and implementing measures; the advantages medium and long-term which included the continuity of measures to meet the priorities and short and medium term as well as strategies for the approximation of legislation presented in the table below:

\begin{tabular}{|c|c|c|c|c|c|c|c|}
\hline $\begin{array}{c}\text { No of } \\
\text { identification }\end{array}$ & $\begin{array}{c}\text { Domestic } \\
\text { measures }\end{array}$ & $\begin{array}{c}\text { EU } \\
\text { measures }\end{array}$ & $\begin{array}{c}\text { Level of approximation } \\
\text { with Acquis }\end{array}$ & Authority & $\begin{array}{c}\text { Translate } \\
\text { Status }\end{array}$ & $\begin{array}{c}\text { Technical } \\
\text { help }\end{array}$ & $\begin{array}{c}\text { Presentation in } \\
\text { Parliament }\end{array}$ \\
\hline & & & & & & & \\
\hline
\end{tabular}

\section{Level of Legal Approximation}

\subsection{Minimum Approximation}

Minimum approximation means that the normative act of the EU provides the legal framework and sometimes even detailed rules on the issue, but the Member States of the EU are free to provide even higher standards. ${ }^{5}$

\subsection{Maximum Approximation}

Maximum approximation means that a certain normative act of the EU (in most cases a directive or a regulation), defines 
the provisions which are not a matter of choice or change. ${ }^{6}$

\subsection{Selective Approximation}

This method is used in cases where the provisions of EU law allow a space for the State Member of the EU to go further, to the introduction of higher requirements than required.

\subsection{Mutual recognition of national legislations ${ }^{7}$}

This method of alignment was defined by the Court of Justice.

\subsection{Approximation by the reference method}

This legal technique refers implementation and compliance with the rules contained by the proper directive, while other issues are in line with normative acts of relevant institutions, such as the Standards Institute. ${ }^{8}$

\subsection{Methodology of the translation of the acquis}

In Albanian case, the translation has been organized through the creation of translation structures originally in the European Integration Ministry (Translation and Coordination Unit). Based on the experience of countries joined the EU, there are two directions in relation to the organization of work and the way of the acquis translation:

- The translation of the acquis by translators outside TCU (Translation and Coordination Unit);

- The translation of the acquis by translators in TCU.

In both ways, translated parts of the acquis are revised by linguistic experts and then by jurists with knowledge in foreign languages. Once the version of legislation is completely reviewed, it is thrown in the "database" CC Vista (installed by the TAIEX program) and it is communicated to the European Commission services, which makes its final certification.

Translation is followed by the creation, processing and exchange of terminology; Cooperation with regional countries participating in the stabilization and association process; Adjusting the structure to begin the process of translation. This management should be reflected in creating the 3 specialties within this structure: translator, linguist and lawyer.

To precede the process of translation of the acquis and the Albanian legislation, the translation sector in the Approximation of Legislation Directorate has prepared and published the following documents:

White Book on the integration in the internal market;

Manual on the use of Community legislation;

Glossary of EU.

\section{Principles and Methods of Approach ${ }^{9}$}

\subsection{The two most important methods}

- The legislative method and

- Method of pro-European interpretation of the law.

It should be noted that the best method of approach is the legislative method. This method consists in law harmonization through amending legislation, as well as creating new laws if necessary.

Most of the approximation is related to the secondary legislation, as specified in Article 249 of the Treaty of Rome. Upon accession, regulations issued by the Commission, start to apply directly. Thus, the implementation of the regulation

\footnotetext{
${ }^{6}$ Directive 2009/54/EC of European Parliament and European Council, 18 June 2009

7 Cases "Dassonville" and "Cassis de Dijon"

${ }^{8}$ 2004/108/EC of European Parliament and European Council, 15 December, 2004

${ }^{9}$ https://www.scribd.com/doc/33741493/Itap-materiali-Perafrimi-Legjislacionit-Me-Be\#scribd 
will automatically replace national legislation. Somewhat the situation is easier about directives. In this case, it is required to take some measures by the states for their implementation.

As explained earlier, part of the acquis is also the jurisprudence of the Court of Justice, which does not require a genuine process of approximation, but an interpretation of domestic legislation in the light of the decisions of this court.

The second method of approximation is the European interpretation of domestic legislation. It should be noted that this is the easiest method. But despite this fact, it cannot be used to avoid legal difficulties.

\subsection{The main stages in the process of legal approximation}

- Preparatory phase: the establishment of institutions necessary for legislative approximation and a series of technical activities including distribution and presentation of legal acts of the EU in specific areas as well as presentation of the principles of in general legal approximation;

- Analysis phase: definition of priorities based on national priorities and on the future international arrangements, the translation of the necessary legal acts of EU and their inclusion in the National Integration Plan, in accordance with the priorities set in advance;

- Relocation: In this stage, it is reached to approximate the legislation with the right of EU. National experts, with the help of experts of the EU, where appropriate, should prepare draft laws or propose amendments to existing laws and regulations, in order to achieve compliance with EU law;

- Implementation: important is not only the adoption of new laws or amendments to existing laws or regulations in Parliament, but also their appropriate application in practice and the management of their effect on existing institutional infrastructure.

- Empowerment: after the adoption of legal acts, necessary measures required by the competent authorities to ensure that the law is fully and properly respected and that the performance of sector policies has improved.

\section{Conclusions}

Legal approximation process is the largest and most comprehensive task in the accession process. Approximation process includes methods and techniques to transpose EU legislation into national law, its inclusion in national legal systems and the process of implementation, which is manifested through realization of individual rights or assumption of concrete obligations.

Treaties establishing the EU use different terms as: harmonization, alignment, and coordination. These three terms sometimes express different levels of integration processes that have been reached between the Member States of the EU.

Drafting laws is a real challenge. However, the involvement of the EU legal acts in national legislation is an even greater challenge. Before drafting a law, we need proper planning policies. After drafting the law, the next important step is the implementation and enforcement. Therefore, the elaboration of a draft law is only one part of the process of legal approximation.

This paper treats the legal Approximation (Step by Step), national priorities and harmonizing legislation, identification of the legal act of the EU, analysis of national legislation, choosing the right type of internal legal act for transposition, drafting the law and legal transposition, and drafting the Concordance Table and Statement of Compliance. Albania has already started the transposition of the EU legislation (primary and secondary sources), since the SAA has been signed. Nowadays Albania is in the right way toward translating, harmonizing, and implementing the harmonized laws. Also the justice system, especially courts, is implementing the European Justice Court decisions.

The main aim of Albania is being part of EU through becoming a member state, so the obligations set by the SAA (2006) and also the Copenhagen Summit (1993) are taken seriously by the Government.

\section{References}

http://eur-lex.europa.eu/en/index.htm;

https://www.scribd.com/doc/33741493/Itap-materiali-Perafrimi-Legjislacionit-Me-Be\#scribd;

Case of "Van Gend en Loos vs. Netherlands", ECJ 26/1963;

Article 5 of European Community Treaty;

Articles 12, 141, 251 of European Community Treaty;

CE Directive 2003/9/EC, 27January, Official Journal L 031, 06.02.2003, pg. 0018-0025; 
Directive 2009/54/EC of European Parliament and European Council, 18 June 2009; Cases "Dassonville" and "Cassis de Dijon";

2004/108/EC of European Parliament and European Council, 15 December, 2004;

https://www.scribd.com/doc/33741493/Itap-materiali-Perafrimi-Legjislacionit-Me-Be\#scribd;

Stabilization an Association Agreement between Albania and the EU, 2006. 